\title{
Analysis of proximate composition and consumer preference of three reef fish species
}

\author{
D.M.A. EDIRISINGHE ${ }^{1}$, P.R.T. CUMARANATUNGA ${ }^{1}$, K. \\ RADAMPOLA $^{1}$ and P.T. KIRINDEARACHCHIGE ${ }^{2}$ \\ ${ }^{1}$ Department of Fisheries and Aquaculture, ${ }^{2}$ Department of Limnology, \\ Faculty of Fisheries and Marine Sciences \& Technology. University of \\ Ruhuna, Matara, Sri Lanka. \\ *Corresponding author (anushaedirisinghe@gmail.com)
}

\begin{abstract}
Reef fishery plays a very important role in the coastal fishing of Sri Lanka and also there is a belief that some reef fishes provide special health benefits. However, the information available on chemical composition of reef fish is very limited. This study is based on the consumer preference survey conducted through an interview of 60 consumers at three retail markets in Sri Lanka namely Dondra, Matara and Weligama. Proximate composition was also analyzed for three highly consumer preferred reef fish species. A total of 34 fish, representing at least 11 specimens from each of the three fish species were analyzed for moisture, protein, lipid, ash and the total energy content. Gonado-somatic index (GSI), hepato-somatic index (HSI) and condition factor (K) were also calculated from January to April 2012.

It was revealed that consumers highly preferred Lethrines olivaceus (Longface emperor) (27\%) whereas preference for Epinephelus merra (Honey comb grouper) and Lutjanus rivulatus (Blubber-lip snapper) were $17 \%$ and $9 \%$ respectively. Two way ANOVA showed no significant difference in the moisture and ash content among three species, but there was a significant difference $(\mathrm{p}<0.05)$ in protein and fat content. Highest protein content was in E. merra $(89 \%)$, while its lipid content was $5-8 \%$ (of the dry weight). Three species had condition factors above 1.7, which indicates their relative healthiness, with respect to food and space within the southern coastal waters of Sri Lanka. E. merra had the highest GSI values while $L$. olivaceus and $L$. rivulatus had the lowest and intermediate values respectively, which can be related to their gonadal development stage. The HSI was negatively related to total energy of females of E. merra and L. olivaceus, which could be due to energy reservation in liver than in muscles for their reproduction, while in L. rivulatus such a trend was not evident possibly due to prominent lipid storage structures within their body cavity. E. merra had the highest energy content $\left(5.82 \mathrm{~kJ} \mathrm{~g}^{-1}\right)$ and consumers expressed their belief on its suitability for consumption with a view to reduce cholesterol level $(80 \%)$.
\end{abstract}


Keywords: Serranidae, Lethrinidae, Lutjanidae, condition factor, gonado-somatic index, hepato-somatic index

\section{Introduction}

Fish products have been identified as an important and cheap source of nutrients such as protein, lipid and minerals (Dahl et al. 2006). In Sri Lanka fish products are mainly supplied to the consumer by capture and culture fisheries. These two sectors play an indispensable role in the economy of Sri Lanka contributing around 1.2\% to the GDP (Fisheries Research Institute 2004). Rajan (2003) reveals that groupers and snappers are popular marine food fish of highest market value in many parts of the world and few are currently being exported in frozen form. Johnston (2007) also stated that coral reef fishes are commercially very important. Some species such as groupers and snappers are high-valued food fish and are emerging as aquaculture commodities in tropical and subtropical countries due to increasing demand.

In the present study, proximate composition of three selected marine reef fish species namely Epinephelus merra, (Honey comb grouper) Lutjanus rivulatus (Blubber-lip snapper) and Lethrinus olivaceus (Long-face emperor) was examined. These species are commercially important and commonly available in Sri Lankan fish markets. Also they have a high demand among tourists. Selection of fish species for this study was based on a preliminary investigation on consumer preference, and fish species highly preferred by consumers were selected. Despite the importance of these species, seasonal variation in their proximate composition is not well known. This study was therefore designed to examine the differences of proximate composition and energetic value of these three fish species captured within the Southern coastal belt of Sri Lanka. Questionnaire based interviews targeted the identification of beliefs of consumers regarding the health benefits of these species.

The reasons for particular food choices among consumers are complex and diverse. The food consumption, like any other complex human behavior, is influenced by many interrelating factors, such as food quality aspects (e.g. flavour, texture, and odor), characteristics of the individual (e.g., personality, preferences, attitudes, perceptions, and knowledge), etc. (Furst et al. 1996; Olsen 2001). The consumers' preferences and attitudes are always of the foremost importance for fisheries, leading to an improvement of fishing techniques for desired species and post-harvest technology, which helps to improve the consumer attraction and acceptability. In this frame, the fish consumer is an important link between supply and demand. The knowledge on preferences might catalytically contribute to the improvement of the terms of production and fish distribution, and the quality of the captured species and their processed products.

\section{Materials and Methods}

The consumer attitude survey was conducted from January to April 2012 using the people visiting three fish retail markets viz., Dondra, Matara and Weligama in the Southern province between $7.30 \mathrm{am}$ to $10.30 \mathrm{am}$. They were randomly chosen twice 
a week and interviewed on-site by using a structured questionnaire. A total of 60 customers (20 from each site) were interviewed and data such as their age, frequency of consumption of reef fish, the most preferred species and the reasons for preference and their general beliefs on the health benefits of reef fish were recorded.

The proximate composition analysis was performed on the most preferred reef fish species identified by the questionnaire survey. Species selected were Epinephelus merra (Honey comb grouper (E); Gal Kossa (S); Serranidae,), Lethrinus olivaceus (Long face emperor (E), Uru hota (S); Lethrinidae,) and Lutjanus rivulatus (Blubber-lip snapper (E), Bedava (S); Lutjanidae). The fish samples were collected during the two months period from February to March 2012. A total of thirty four fish $(12 \mathrm{E}$. merra, $11 \mathrm{~L}$. olivaceus and $11 \mathrm{~L}$. rivulatus $)$ were purchased from retail market and were immediately packed in crushed ice, transported to the laboratory in polystyrene boxes and were frozen until further analysis. Subsequently, the fish were cleaned and dried.

The total length (TL) was taken to nearest $0.1 \mathrm{~cm}$ using a measuring board and total weight (TW) of fish was determined to the nearest $0.01 \mathrm{~g}$ by an analytical balance. The specimens were dissected and sexes were identified based on the appearance of the gonads. Liver weight (LW), gonad weight (GW), condition factor (K) (Richter et al. 2000), gonado-Somatic Index (GSI) (Afonso-Dias et al. 2005) and hepato-somatic index (HSI) (Rajaguru 1992) were calculated for each fish species.

\section{Proximate analysis}

Muscle portion avoiding the belly flap was used in moisture content analysis (AOAC 1989). Protein, lipid and ash contents were determined using standard techniques (AOAC 1989). All samples were analyzed in duplicate and results were reported on dry weight basis except for the total energy $(\mathrm{g} / 100 \mathrm{~g})$. The energetic value was determined indirectly using Rubner's coefficients for aquatic organisms. $9.5 \mathrm{kcal} \mathrm{g}^{-1}$ for lipids, $5.65 \mathrm{kcal} \mathrm{g}^{-1}$ for proteins (Winberg 1971), and expressed in $\mathrm{kJ}$ $\mathrm{g}^{-1}$ wet mass as described by Eder and Lewis (2005).

\section{Statistical analysis}

Two-way ANOVA model with interaction was used to evaluate the association of proximate composition with fish species and sex using SPSS software programme (SPSS version 16.0). The significance level of 0.05 was applied to all statistical tests.

\section{Results}

\section{Consumer preference survey}

The consumers interviewed in the survey comprised only of local consumers $(100 \%)$. Among them, $75 \%$ of the respondents were males and remaining $25 \%$ were 
females. The most popular reef fish species due to the taste was Lethrinus olivaceus, Epinephelus merra and Lutjanus rivulatus among 27\%, 17\% and $9 \%$ of the respondents respectively. $88 \%$ preferred coral reef fish. Main reasons for disliking were taste $(43 \%)$ and high price $(29 \%)$. Of the reef fish consumers $81 \%$ had been consuming fish for over 10 years. When selecting reef fish for consumption (Figure 1) freshness of fish was the most important factor considered by $68 \%$ of the respondents. The next most important factors were the type of fish species $(21 \%)$, followed by the nutrition value $(8 \%)$. The price and taste were considered as an important factor only by $2 \%$ of respondents for both categories.

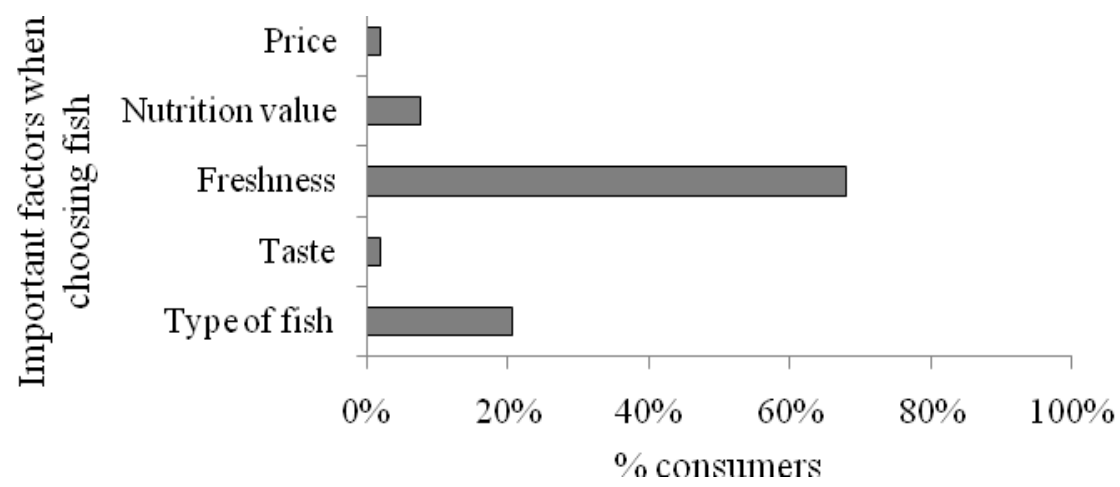

Figure 1. The most important factor considered by the consumers when selecting reef fish

Among consumers responded, main beliefs behind selection of reef fish were ability to reduce the cholesterol level of consumers $(60 \%)$ and, reduce heart diseases (20\%). When consider about the better fish species for health benefits, $80 \%$ of the respondents clearly stated that E. merra is the best fish species when compared to other two.

\section{Condition factor}

The mean \pm SD for condition factor for females was $2.06 \pm 0.16$ in E. merra, $2.03 \pm 0.22$ in L. olivaceus and $1.81 \pm 0.21$ in L. rivulatus, and for males it was $2.01 \pm 0.1$ E. merra, $1.72 \pm 0.23$ of L. olivaceus, and $3.02 \pm 0.53$ of L. rivulatus. In $L$. rivulatus the condition factor was significantly higher than the other two (Table 1).

Gonado-somatic index

The mean $\pm \mathrm{SD}$ for gonado-somatic index for females was $0.59 \pm 0.08$ in E. merra, $0.32 \pm 0.09$ in $L$. olivaceus and $0.42 \pm 0.08$ in L. rivulatus and for males it was $0.07 \pm 0.01$ in E. merra, $0.13 \pm 0.01$ in L. olivaceus and L. rivulatus $0.12 \pm 0.01$ (Table 1). 


\section{Hepato-somatic index}

The mean $\pm \mathrm{SD}$ for hepato-somatic index for females was $2.41 \pm 0.15$ in $E$. merra, $1.12 \pm 0.13$ in L. olivaceus, and $1.51 \pm 0.20$ in L. rivulatus and in males it was $1.58 \pm 0.19$ in E. merra, $1.22 \pm 0.07$ in L. olivaceus and $0.57 \pm 0.07$ in L. rivulatus (Table 1).

\section{Proximate composition analysis}

Biological parameters, proximate composition and total energy of females and males of three species of reef fish are given in Table 1. The results of twoway ANOVA indicated that there was a significant difference in $\%$ crude protein content among three reef fish species $\left(\mathrm{F}_{2,28}=4.670, \mathrm{P}=0.018\right)$. Similarly, \% crude fat content among three fish species was also significantly different $\left(\mathrm{F}_{2,28}=5.996 ; \mathrm{p}\right.$ $=0.007)$. However, $\%$ moisture content $\left(\mathrm{F}_{2,28}=2.892 ; \mathrm{p}>0.05\right)$ and $\%$ ash content $\left(\mathrm{F}_{2,28}=1.337 ; \mathrm{p}>0.05\right)$ of muscles were not significantly different among three reef fish species. The mean energetic values were also found to be significantly different among three fish species (Two-way ANOVA; $\mathrm{F}_{2,28}=5.193, \mathrm{p}=0.012$ ).

These results further indicated that E. merra had the highest GSI values while L. olivaceus and L. rivulatus had the lowest and intermediate values respectively, which can be related to their gonadal development stage. Although not tested statistically, it was apparent that HSI was negatively related to total energy of females of E. merra and L. olivaceus, which could be due to energy reservation in liver than in muscles for their reproduction, while in L. rivulatus such a trend was not evident possibly due to prominent lipid storage structures within their body cavity.

\section{Discussion}

Results suggest that in the study area male consumers predominate in purchasing fish. Therefore, their attitudes towards fish are important. Majority of them are elite consumers and are not considering the price or white muscle taste due to their positive attitudes towards reef fish. The consumers adopted the norm of eating reef fish with the belief that it is a better method to reduce cholesterol levels, and also as a better food for heart diseases. To test the knowledge for above norms, in structured questionnaire as a health benefit - "good for vision" was included. Nevertheless, none of any respondents suggested it as a benefit of eating reef fish. In other words, the reef fish consumers in this region have specified health benefits from consuming certain reef fish species. When considering these health benefits, E. merra was considered as highly important to reduce the cholesterol levels. Nevertheless, when surveyed about the preference for the taste, L. olivaceus was highly preferred than other two fish species. When purchasing reef fish from the market, consumers consider freshness as the most important factor. The reason for 
this is the consumers' belief that the healthy oil in reef fish deteriorates with the time. Therefore, the fresh reef fish has a very high demand in the market. The major reason for disliking reef fish was the taste of their white muscle, because most of the people in tropical countries such as Sri Lanka highly prefer the taste of red muscle. Other reasons were their high price and unavailability in the market. This could be due to the lack of a well planned market chain in Sri Lankan fishery industry.

Table 1. Mean \pm SD of biological parameters, proximate composition and total energy of females and males of three species of reef fish.

\begin{tabular}{|c|c|c|c|c|}
\hline Fish species & & E. merra & L. olivaceus & L. rivulatus \\
\hline \multirow{2}{*}{ Sample no. } & Female & 8 & 7 & 7 \\
\hline & Male & 4 & 4 & 4 \\
\hline \multirow{2}{*}{ Total length $/ \mathrm{cm}$} & Female & $27.75 \pm 0.53$ & $28.14 \pm 0.55$ & $27.76 \pm 0.63$ \\
\hline & Male & $31.58 \pm 0.93$ & $31.08 \pm 0.76$ & $31.13 \pm 0.69$ \\
\hline \multirow{2}{*}{ Total weight/g } & Female & $441.34 \pm 59.17$ & $451.85 \pm 46.77$ & $387.89 \pm 57.22$ \\
\hline & Male & $632.16 \pm 52.09$ & $513.48 \pm 35.85$ & $959.53 \pm 113.73$ \\
\hline \multirow{2}{*}{ K } & Female & $2.06 \pm 0.16^{\mathrm{b}}$ & $2.03 \pm 0.22^{\mathrm{b}}$ & $1.81 \pm 0.21^{\mathrm{a}}$ \\
\hline & Male & $2.01 \pm 0.1^{\mathrm{a}}$ & $1.72 \pm 0.23^{\mathrm{a}}$ & $3.02 \pm 0.53^{\mathrm{b}}$ \\
\hline \multirow{2}{*}{ GSI } & Female & $0.59 \pm 0.08^{b}$ & $0.32 \pm 0.09^{\mathrm{a}}$ & $0.42 \pm 0.08^{b}$ \\
\hline & Male & $0.07 \pm 0.01^{\mathrm{a}}$ & $0.13 \pm 0.01^{b}$ & $0.12 \pm 0.01^{\mathrm{a}}$ \\
\hline \multirow{2}{*}{ HSI } & Female & $2.41 \pm 0.15^{\mathrm{b}}$ & $1.12 \pm 0.13^{\mathrm{a}}$ & $1.51 \pm 0.20^{\mathrm{b}}$ \\
\hline & Male & $1.58 \pm 0.19^{\mathrm{b}}$ & $1.22 \pm 0.07^{\mathrm{b}}$ & $0.57 \pm 0.07^{\mathrm{a}}$ \\
\hline \multirow{2}{*}{ Moisture* } & Female & $74.31 \pm 1.78^{\mathrm{a}}$ & $77.11 \pm 1.49^{\mathrm{a}}$ & $75.75 \pm 1.00^{\mathrm{a}}$ \\
\hline & Male & $77.17 \pm 0.38^{\mathrm{a}}$ & $75.39 \pm 0.82^{\mathrm{a}}$ & $73.98 \pm 1.28^{\mathrm{a}}$ \\
\hline \multirow{2}{*}{ Protein\# } & Female & $89.61 \pm 1.43^{b}$ & $86.24 \pm 3.48^{\mathrm{a}}$ & $88.46 \pm 2.65^{b}$ \\
\hline & Male & $89.96 \pm 1.64^{b}$ & $89.00 \pm 4.70^{\mathrm{b}}$ & $87.86 \pm 1.71^{\mathrm{a}}$ \\
\hline \multirow{2}{*}{ Fat\# } & Female & $8.30 \pm 3.81^{\mathrm{b}}$ & $3.25 \pm 1.52^{\mathrm{a}}$ & $6.23 \pm 1.16^{\mathrm{b}}$ \\
\hline & Male & $5.44 \pm 1.72^{b}$ & $3.27 \pm 1.37^{\mathrm{a}}$ & $5.11 \pm 0.93^{b}$ \\
\hline \multirow{2}{*}{ Ash\# } & Female & $5.36 \pm 0.56^{\mathrm{a}}$ & $5.50 \pm 0.58^{\mathrm{a}}$ & $5.58 \pm 1.11^{\mathrm{a}}$ \\
\hline & Male & $5.67 \pm 0.88^{b}$ & $4.81 \pm 0.61^{\mathrm{a}}$ & $5.04 \pm 0.69^{b}$ \\
\hline \multirow{2}{*}{$\begin{array}{l}\text { Total energy* } \\
\mathrm{kJg}^{-1}\end{array}$} & Female & $6.29 \pm 0.59^{\mathrm{b}}$ & $4.96 \pm 0.34^{\mathrm{a}}$ & $5.64 \pm 0.36^{\mathrm{a}}$ \\
\hline & Male & $5.35 \pm 0.17^{\mathrm{a}}$ & $5.50 \pm 0.04^{\mathrm{b}}$ & $5.95 \pm 0.3^{\mathrm{b}}$ \\
\hline
\end{tabular}

In each row, values with the different superscripts $(a, b)$ in both males and females for each factor are significantly different among reef fish species at $95 \%$ confidence level.

*Fresh wet mass.

\#Dry mass (wet values=dry value*[1-proportion of water]). 
Condition factor was used to compare the growth conditions of fish and a quantitative parameter of the well-being of fish and it reflects recent feeding conditions. A high condition factor reflects good environmental quality; while a low condition factor reflects poor environmental quality (Le Cren 1951). According to the observation of this study, all three fish species have condition factor higher than 1.7, which indicates that the reef environment in the Southern region provides good living conditions for reef fish. Gonado-Somatic Index (GSI) is generally used to estimate reproductive condition. Sampling was done during the February to April, which was coinciding with the spawning season of E. merra (Randall and Brock 1960). Therefore, the highest GSI value in female E. merra could be due to the reason that they were in the highest gonadal maturity stage. The spawning period of L. rivulatus is from May to October and peaks in July (Grimes 1987). Therefore during the present investigation, L. rivulatus was at an intermediate gonadal maturity stage at the period of sampling and they showed an intermediate GSI value. L. olivaceus whose spawning period ranged from September to October (Currey et al. 2009) had the lowest GSI values, which indicates that they were at a lower gonadal maturity stage. Furthermore, GSI is not a reliable indicator of annual spawning activity for males, because unlike female oocytes, which gain weight prior to spawning (higher GSI), male testes become lighter with onset of spermatogenesis (lower GSI) (Stoumboudi et al. 1993). Hepato-somatic Index (HSI) provides an indication on status of energy reserve in an animal. In a poor environment, fish usually have a smaller liver (with less energy reserved in the liver). The HSI value was significantly different between males and females of three fish species. In the present study, HSI is a good indicator of total energy of females of E. merra and L. olivaceus as there was an apparent negative relationship between HSI and total energy value of their muscles. This could be due to energy reservation in liver than in muscles for their reproduction. However, L. rivulatus is a fish which has lipid storage structures in their body cavity. In general they are called as fatty parts. Therefore, the lipid storage in the liver could be lower in L. rivulatus than other two species. This aspect needs further investigations.

In the proximate composition of fish muscles, E. merra had $74.31-77.17 \%$ moisture $\%, 23.02 \%-20.54$ protein $\%, 2.13 \%-1.24 \%$ fat and $1.38 \%-1.29 \%$ ash (wet weight basis). These results are in agreement with the observations of Hanna (2001) who reported that proximate composition of E. merra in Red sea as $77.64 \%$ moisture, $19.83 \%$ protein, $1.15 \%$ fat and $1.58 \%$ ash content. Aitken et al. (2011) have investigated the proximate composition of muscles of Lethrinids ( $L$. olivaceus). The proximate values of muscles in their investigation were moisture $78.06 \%$, protein $20.02 \%$, fat $1.12 \%$ and ash $1.27 \%$. These values also are in agreement with those of the present study [moisture $77.11 \%-75.39 \%$, protein $19.74 \%-21.90 \%$, fat $0.74 \%-0.80 \%$ and ash $1.26 \%-1.18 \%$ (wet weight basis)]. Also Boran and Karacam (2011) have reported the proximate composition of muscles of Lutjanidae (L. rivulatus) as moisture $77.37 \%$, protein $20.00 \%$, fat $1.22 \%$ and ash $1.58 \%$. The proximate composition of L. rivulatus in the present study is comparable to them [moisture $75.75 \%-73.98 \%$, protein $21.31 \%-22.91 \%$, fat $1.51 \%-1.33 \%$ and ash $1.35 \%-1.31 \%$ (wet weight basis)]. 
Lipids are the primary energy storage material in fish. Thus, the lipid content of a fish indicates the surplus energy available for future maintenance, growth, and reproduction (Love 1970; Adams 1999; Tocher 2003). The present observations on the proximate composition of the muscle demonstrated that the females presented significantly higher mean fat values than those of males for $E$. merra (2.13\% and $1.24 \%$ respectively). Hanna (2001) found that reef fish species in the Red Sea characterized by low fat content $(<2.3 \%)$ and very high protein content $(15 \%-23.6 \%)$. Marinkovic and Zei (1959) also have reported similar results. During the present study, the fat content was $<2.19$ and the protein content varied between $19.74 \%$ and $23.02 \%$ which are in agreement with the observations of Marinkovic and Zei (1959) and Hanna (2001). The proportionally high protein content in reef fish compared to many other fish species may be an adaptation to low food intake periods such as spawning period. Total energy values was calculated using protein and fat content and during the present study E. merra female had the highest energy value $\left(5.82 \mathrm{kJg}^{-1}\right)$ followed by $L$. olivaceus male $\left(5.79 \mathrm{~kJ} \mathrm{~g}^{-1}\right)$.

Generally, reef fish are low in fat contents, but are excellent sources of protein. However, findings of this study have noticed slight differences in the composition when compared to those of other previous studies. There can be many possible factors for these differences, such as size, sex, maturity of samples and sampling locations that can affect the differences in proximate composition of marine fish. Also the belief of people that reef fish have ability to reduce cholesterol level should be further investigated including studies on fatty acid profiles of different reef fish species. This kind of analysis could significantly contribute to the reef fishery industry and for healthy reef fish consumption habits among consumers.

\section{Acknowledgments}

The authors wish to expresses their sincere thanks to Department of Fisheries and Aquaculture, Faculty of Fisheries and Marine Sciences \& Technology, University of Ruhuna, Sri Lanka for the valuable support provided to conduct this study. The first author (D.M.A.E.) would also like to thank Dr. Sevvandi Jayakody of Wayamba University of Sri Lanka, Sri Lanka Association for Fisheries and Aquatic Resources and Bay of Bengal Large Marine Ecosystems Project for the assistance provided for preparation of the manuscript through a training programme on manuscript writing.

\section{References}

Adams, S.M. 1999.

Ecological role of lipids in the health and success of fish populations. In: Lipids in Freshwater Ecosystems (M.T. Arts \& B.C. Wainman eds). Springer-Verlag, New York. pp. 132-160.

Afonso-Dias, I., C. Reis \& P. Andrade 2005.

Reproductive aspects of Microchirus azevia (Risso, 1810) (Pisces:

Soleidae) from the south coast of Portugal. Scientia Marina 69(2): 275-283. 
Aitken, A., A. Lees, \& J.G.M. Smith 2011.

Measuring fish composition. Torry Research Station. [online] Available at: $<$ http://www.fao.org/wairdocs/ tan/ x5957E/x5957e00.html $>$ [Accessed 15 September 2011].

AOAC 1989.

Official Methods of Analysis. Association of Analytical Chemists. $15^{\text {th }}$ edition. Arlington, Virginia, USA.

Boran, G. \& H. Karacam 2011.

Seasonal Changes in Proximate Composition of Some Fish Species from the Black Sea. Turkish Journal of Fisheries and Aquatic Sciences 11: 1-5.

Currey, L.M., A.J. Williams, C.A. Simpfendorfer, A.C. Ballagh \& A.L. Penny 2009. Comparative biology of key inter-reefal lethrinid species on the Great Barrier Reef. Project Milestone Report to the Marine and Tropical Sciences Research Facility. Reef and Rainforest Research Centre Limited, Cairns. 29 p.

Dahl, L., T. Bjørkkjaer, I.E. Graff, M.K. Malde, \& B. Klementsen 2006.

Fish more than just omega 3. Tidsskrift for den Norske Laegeforening 126(1): 309-311.

Eder, B.B. \& M.N. Lewis 2005.

Proximate composition and energetic values of demersal and pelagic prey species from the SW Atlantic Ocean. Marine Ecology Progress Series 291(1): 43-52.

Fisheries Research Institute 2004.

Field guide to selected commercial marine fishes of Malaysian waters. Fisheries Research Institute, Kuala Lumpur, Malaysia.

Furst, T., M. Connors, C.A. Bisogni, J. Sobal \& L.W. Falk 1996.

Food choice: a conceptual model of the process. Appetite 26: 247-266.

Grimes, C.B. 1987.

Reproductive biology of the Lutjanidae: a review. In: Tropical Snappers and Groupers: Biology and Fisheries Management (J.J. Polovina \& S. Ralston eds). Ocean Resources and Marine Policy Service. West View Press, Inc., Boulder and London. pp. 239-294.

Hanna, R.G.M. 2001.

Proximate composition of Certain Red Sea fishes. Marine Fisheries Review 46(3): 71-74.

Johnston, B. 2007.

Economics and marked analysis of the live reef-fish trade in the AsiaPacific region. ACIAR Working Paper No.63, Australian Centre for International Agricultural Research, Canberra.

Le Cren, E. D. 1951.

The length-weight relationship and seasonal cycle in gonad weight and the perch Perca fluviatilis. Journal of Animal Ecology 20(2): 201 - 219.

Love, R.M. 1970.

The Chemical Biology of Fishes. Academic Press, Inc. London, U.K. 547 p. 
Marinkovic, M., \& M. Zei 1959.

The nutritive value of fish flesh considered in relation to the ecology of fishes. Bulletin of Science Yugoslavia 4(1): 110.

Olsen, S.O. 2001.

Consumer involvement in seafood as family meals in Norway: an application of the expectancy-value approach. Appetite 36(1): 173-186.

Rajaguru, A. 1992.

Biology of two co-occurring tongue fishes, Cynoglossus arel and C. lida (Pleuronectiformes: Cynoglossidae), from Porto Nova, southeast coast of India. Fishery Bulletin 90(1): 328-367.

Rajan, P.T. 2003.

A Field Guide to Marine Food Fishes of Andaman and Nicobar Islands. $1^{\text {st }}$ Edition. Zoological survey India, Kolkata.260 p.

Randall, J.E. \& V.E. Brock 1960.

Observations on the ecology of Epinephelidae and Lutjanidae fishes of the Society Islands, with emphasis on food habits. Transactions of the American Fisheries Society 89(1): 9-16.

Richter, H., C. Christian Lückstädt, U.L. Focken, \& K. Becker 2000.

An improved procedure to assess fish condition on the basis of lengthweight relationships. Archive of Fishery and Marine Research 48(3): 226235.

Stoumboudi, M. T., W. Villwock, J. Sela, \& M. Abraham 1993.

Gonadosomatic index in Barbus longiceps, Capoeta damascina and their natural hybrid (Pisces, Cyrinidae), versus spermatozoan index in parental males. Journal of Fish Biology 43(1): 865-875.

Tocher, D. 2003.

Metabolism and functions of lipids and fatty acids in teleost fish. Reviews in Fisheries Science 11(1): 107-184.

Winberg, G.C. 1971.

Methods for Estimation of Production of Aquatic Animals. Academic Press, New York. 